\title{
SPARE RIBS? EARLY MODERN FEMALE MONASTICISM IN THE EAST SLAVIC LANDS*
}

Liudmyla Sharipova

University of Nottingham

\begin{abstract}
In contrast to the robust state of research on female Catholic monasticism in Central and Western Europe, Italy and the Iberian Peninsula, the history of Orthodox and Greek Catholic convents in the Balkans and Eastern Europe remains a largely uncharted field of study. Although historical archives in those parts of Europe offer rich pickings of firstclass documentary material, the lack of up-to-date research methodologies in postSocialist countries, the current stunted condition of pre-modern Slavic studies in Western Europe, and occasional problems of archival access create obstacles against the development of this promising area of research. However, characteristic of a strong element of human interest, research on early modern women's monasticism of the Eastern Rite has the potential to broaden the awareness of the place women held in European societies and cultures of the past and contribute to a more nuanced understanding of it at present.
\end{abstract}

'Nuns have recently attracted many fans', we are told. ${ }^{1}$ The truth of this statement, specifically with regard to early modern Roman Catholicism, is evident from the sheer volume of publications in the last twenty years. Indeed, even a list of select publications in English looks impressive. ' ${ }^{2}$ Family history, welfare and educational history, a new kind of religious history, and perhaps - above all - cultural history and the preoccupation with textual analysis, have all found the nun relevant to their unfolding concerns' ${ }^{3}$ One would be hard put, however, trying to identify a comparable body of research when it comes to Eastern Christianity. ${ }^{4}$ For earlier periods some excellent work has been produced by the historians of Byzantium. ${ }^{5}$ More recently the historians of early modern Christianity in the Middle East have offered a number of contributions that discuss postTridentine Melkite and Maronite female monasticism, principally in Lebanon and Syria. ${ }^{6}$ But it would not be straining the point to describe the amount of research done on the female religious in South-Eastern and Eastern Europe as sparse. 
Prior to the collapse of the Soviet Union, the studies of Russian Orthodox monastic institutions were conducted within the dominant paradigm of 'progressive' Marxist history and focused almost exclusively on the economic aspects of their life, such as monastery landholdings and their dependent peasants. Women's monasticism was not considered separately, if at all, and was evidently regarded as marginal or even irrelevant. This resulted in comments even from respectable historians to the effect that only battered wives and sick women chose to take the habit, an opinion, which contemporary documentary evidence manifestly contradicts. ${ }^{7}$ A handful of works published over the last thirty years or so explore convents in early modern Muscovite Russia. ${ }^{8}$ Sophia Senyk's seminal monograph that came out in the early 1980s still remains the only work of this scale in English offering a summary of female monasticism in pre-modern Belorussia and Ukraine. ${ }^{9}$ A small body of research, mostly in non-Western European languages, has been produced in the last ten years by the historians of early modern Ukraine. The Ukrainian scholar Oleg Dukh works on the Greek Catholic (Uniate) convents in Western Ukraine. ${ }^{10}$ His compatriot Olga Krainia, studies early modern Orthodox women's monasteries in Kiev. ${ }^{11}$ A few more isolated contributions to the subject can be found in academic periodicals. ${ }^{12}$ In sum, however, true to St Paul's admonition that women's voices should not be heard, both Eastern Orthodox and Greek Catholic nuns still keep their silence.

This resounding silence has little to do with the lack of primary sources. It reflects the paucity of research in early modern East Slavic women and gender studies more generally. Compared with what Merry Wiesner-Hanks refers to as a veritable 'explosion' or 'flood' of research in regard to Western Europe and the Americas, the historiography of Slavic women to date is represented by a limited number of contributions published in specialised academic journals and edited collections, and a few monographs. ${ }^{13}$ The focus of attention is yet again on Muscovite Russia, while other parts of Europe where Eastern Church rites were practised, remain shrouded in obscurity and sometimes also a degree of misapprehension. Part of the problem is, of course, the enormous complexity of the historical and political make-up of the region. For example, the terms 'Russia', 'Eastern Europe' and the 'Orthodox Church' are often used interchangeably, with no regard for the regional, confessional or ethnic nomenclature. ${ }^{14}$ Different historians' interpretation of 
the ethnic and confessional boundaries of 'Eastern Europe' is sometimes arbitrary and misleading. This area of scholarship also remains heavily dependent on the measure of an individual researcher's linguistic training and the logistics of getting access to the archives.

Other cultural and institutional hurdles exist. Against the pronounced legalism of Roman Catholicism from the Middle Ages onward, the outlook and regulatory practices of Eastern Orthodoxy have famously remained static, based on tradition and ancient canon law that took care of the basics, but left the finer details to be worked out according to local conditions and customs. As David Frick puts it, 'in general the West ... was characterised by its highly codified authorities, the East by the practical lack of codification'. ${ }^{15}$ Up until the end of the early modern period, this lack of codification included a virtual absence of monastic rules. ${ }^{16}$ This consideration acquires particular significance if we bear in mind that, unlike the oft-disputed but generally accepted papal primacy in the Roman Church, the Orthodox ecclesiastical authority has never been effectively centralised at any point in its history. It resides not in the combined ecclesiastical power of its patriarchs, whose number (in reverse proportion to their relative clout) has been growing exponentially from the late sixteenth century, but in the authority of the so-called ecumenical councils. This meant that no unified confession of the Orthodox faith has ever been agreed upon. To this should be added extreme variation in the social and political conditions of the Eastern Churches' existence through the ages. In the early modern period Muscovy was the only country in the world where Eastern Christianity was practised as a state religion. In the rest of Europe, Asia Minor, Middle East and North Africa Orthodox institutions were dominated by Catholic, Muslim or, very occasionally, Protestant rulers. With time the Eastern Orthodox Church became a unified church only in name, loosely held together by a few undisputed fundamentals of dogma. A good example is that in different parts of Europe Orthodox Easter is still annually celebrated on two different dates.

The upshot for the student of the Eastern Orthodox Church is that "vertical history' of the kind successfully practised by the historians of Roman Catholicism is an impossibility. For instance, although the decrees of the Council of Trent concerning the female monastic by no means describe the reality of their existence across Europe in the 
two centuries that followed, they do provide a useful yardstick with which to measure both the degree of their success locally and any changes in interpretation over time. When it comes to writing 'horizontal history', in the sense of providing an analysis of events and phenomena on a 'national' level, the absence of a universal norm with the lack of a unified narrative as its corollary may have an adverse effect on attempts to create balanced large-scale accounts of history where a longue duree perspective is required. ${ }^{17}$ Nor can overarching theoretical frameworks such as Heinz Schilling's 'confessionalisation model' help, for they would not apply in those cases where the Eastern Church was not supported by the states whose rulers and elites adopted an attitude of hostility or toleration to it as being 'schismatic', 'heretic' or 'infidel' ${ }^{18}$

Then there is a problem of sources. In the area of research with which I am most familiar, early modern Ukraine and Russia, primary evidence for the history of the Greek Catholic and the Orthodox Churches exists, although it is patchy. However, the nature of these sources is not what most West European historians of the early modern period would immediately recognise as familiar territory. For example, one would search in vain for 'egodocuments', the writings of personal reflection produced by educated East Slavic individuals who lived in the early modern period, men or women. What Nancy Shields Kollmann says about pre-Petrine Russia: 'personal correspondence, diaries, and ample documentation of an individual's activities and views are virtually non-existent', is equally true of the somewhat more 'westernised' Ukrainians and Belorussians. ${ }^{19}$ They clearly did not pick up the fashion for self-reflection, which was widespread among the politically dominant Catholic and Protestant Polish elite. ${ }^{20}$ It was not until the end of the eighteenth century that a body of native memoiristic writings made its appearance in the East Slavic lands.

Far from being 'ateliers of autobiographical writing' the early modern convents of Russia, Ukraine and Belorussia did not produce a single female monastic writer of the kind exemplified by Teresa of Avila or by the nun chroniclers of the Thirty Years' War. ${ }^{21}$ Outstanding nuns' lives were occasionally written by monks, with whom they shared familial ties or sectarian religious affiliation. ${ }^{22}$ The monastery chronicles coming from the region were written by monks and almost exclusively describe the life of male monastic communities. Neither could this situation be attributed to blanket illiteracy. In the $1770 \mathrm{~s}$ 
the large and prestigious Kiev Sts Florus and Laurus Monastery listed ninety-two of its 121 nuns as literate to some extent. ${ }^{23}$ Nonetheless, apart from copious correspondence concerning the most trivial household matters and occasionally transacted with the highest ecclesiastical authority in the land, it produced no remarkable writings.

Interestingly, even that correspondence was taken down by scribes, and only signed by the women. The one exception is Nataliia Dolgorukaia (1714-1771), who took the veil in the same convent under the monastic name of Nektariia and left a memoir entitled Notes written by oneself (Svoeruchnyie zapiski). Composed in the late1760s, this was a tribute to her late husband and a lament for her own tragic life, but not a spiritual autobiography. ${ }^{24}$ In fact, her narrative stops at the death of her husband nearly two decades before she took the veil in 1758, and reveals no details of Nektariia's life in the Sts Florus and Laurus Monastery, where she spent the rest of her days. The author of the first proper work in this genre penned by a Russian Orthodox nun was Thaisia (18401915), the Mother Superior of the Leushino Convent in the diocese of Novgorod. ${ }^{25}$ Its style and Thaisia's explanation that she undertook the task on direct orders from her confessor bear an uncanny resemblance to what Alison Weber describes as St Teresa's 'rhetoric of humility'. 26

Different, but perhaps not entirely unrelated to this lack of personal reflection is the East Slavic societies' apparent failure to generate theory about society, linked to the absence of a tradition of legal discourse. Up until the time when professions, such as law and medicine, began to emerge closer to the end of our period, a combination of factors such as the non-existence of generally applied legal frameworks like Roman law, characteristic weakness of the urban middle classes and the absence of universities as generators of theoretical enquiry, determined the substitution of essentially confessionbased notions such as 'the Rus', or 'Christian people' for the concept of society as a philosophical and legal entity. When such concepts finally gained currency in the late eighteenth and early nineteenth centuries, they stemmed from the European social and political theories slowly seeping in from the West. ${ }^{27}$ Seen against this cultural background, it is unsurprising that the East Slavic peoples' views about gender roles also remained largely unarticulated, and that the famed querelle des femmes, Renaissance debates about the nature of women, did not spread beyond the borders of Polish Catholic 
culture. ${ }^{28}$ Comparing the situation in Muscovy to that in Western Europe, Kollmann points out the lack of 'learned discussions about the proper roles of men and women', like those provided by 'philosophers in classical antiquity and theologians in medieval Europe', and the absence of 'medical literature on the anatomical differences between the sexes and the correspondingly different social roles to which they destined men and women' as contributing to it. ${ }^{29}$ The available evidence from early modern Belorussia and Ukraine indicates that similar conditions existed in the Orthodox lands of PolandLithuania. However, reading between the lines of official correspondence, sermons, hagiography and chronicles, some information about the extent of gendered spirituality in the East Slav culture can be obtained.

Methodologically, comparative perspectives, interdisciplinary approaches drawing on gender studies and anthropology, and a close examination of the available narrative and literary sources combined with the historian's traditional craft of mining the archives for evidence, hold a considerable promise of opening up avenues of research in the history of early modern women's monastic practices in Eastern Christianity. Potential directions of research may be summarised as follows. First, since '[m] eanings of gender are historically situated ${ }^{30}$, the place of female religious should be examined in conjunction with the wider issue of women's standing in contemporary East Slav societies and cultures. The enquiry should be refined further to reflect how hierarchies of gender mirror those of status. As Wiesner-Hanks reminds us, 'The ability of a woman to act out her religious convictions was largely dependent on class in reality as well as theory'. ${ }^{31}$ It would seem that within the remit of the opportunities open to them, nuns of noble descent provided leadership and represented their convents in ways that went over and above what could be expected even from aristocratic women operating in secular contexts. Even placed at the bottom of the church hierarchy, religious women were in actuality part of it. We need greater knowledge of those contexts, however, before meaningful conclusions can be drawn. The pervading impression of insignificance and powerlessness may have been the result of increasing prevalence of commoners in Orthodox convents toward the eighteenth century compared with their counterparts in Western Europe. ${ }^{32}$ Furthermore, there is no denying that the church, the administrative establishment and the family structures of pre-modern Orthodox societies were 
profoundly patriarchal. However, inasmuch as patriarchal assumptions were generally seen and accepted as a fundamental component of culture, the functioning of patriarchy took complex forms. Thus the misogyny that unquestionably affected these societies was not limited to men alone, as women were not slow to exercise the powers vested upon them by patriarchal structures against other women, sometimes demonstrating how they could work for and against the same individual depending on circumstances. Given the existence of the convents' own hierarchical structures, such considerations may apply to a greater extent in monastic settings than in the context of women's secular lives.

The second, related aspect concerns the convents' public role. While male gender identities were traditionally reinforced by the exercise of public duties, laywomen were widely expected to operate within the private domestic sphere. Catholic nuns' more or less effective enclosure from the sixteenth century on prevented any visible participation in public functions, but they did have a public role nonetheless, which was performed through prayer, the display of relics, as well as other even more intricate means of interaction with society. How did the existence within the convents' 'interstitial sphere of autonomy ${ }^{, 33}$ affect the unenclosed Orthodox nuns or the Greek Catholic nuns, for whom formal enclosure did not arrive until 1720? Cultural and regional variations come into play here. For most of the early modern period, elite Muscovite women observed seclusion in separate quarters and did not appear in public. ${ }^{34}$ Is this an indication that Muscovite convents, some of which had a sizeable proportion of noble women, were effectively enclosed monastic institutions? And if so, how different were they from the Orthodox convents in Ukraine, where no explicit cultural restrictions on women's public appearances ever existed? Such differences highlight the already perceptible dissimilarity in the principles and practice of female monasticism in different parts of the East Slavic lands.

In the third place, a better understanding of women's legal position with regard to property rights, a key component in defining the balance of power between genders, is crucial. Archival evidence shows that East Slavic women left testamentary dispositions, lent money, donated property, got involved in commercial transactions and litigated with relish. However, until a critical mass of research has been accumulated, assessing the degree of correspondence between the legal and social norm, and the practices to whose 
existence these documents testify, is difficult. Administering convent properties and funds empowered their superiors in many and varied ways that impacted not only on the monastery itself, but also on the church hierarchy, as well as the wider community. ${ }^{35}$ In disputes over property rights convents confronted men's monasteries, petitioned individual benefactors and church officials, involved local and central bureaucracies, and often appealed to the crown, creating networks of patronage and influence, which contradicts the impression of apparent marginality arising from their intellectual and spiritual silences. Another aspect of maintaining the gender balance in the legal sphere is respresented by the fact of the long-term survival of the archaic system of mixed or 'double' monasteries among the East Slavs. ${ }^{36}$ Having largely ceased to exist in Catholic Europe by the early fourteenth century, they displayed a substantial staying power in the sphere of Byzantine cultural influences, even despite occasional prohibitions and limitations imposed on them. In Ukraine the last vestiges of the system of double monasteries persisted until the 1770s. In places like Lebanon and Syria double monasteries continued to flourish up until the first quarter of the nineteenth century. Monasteries of mixed sexes were often characterized by their familial origins, and women as well as men could have been the founders and could exercise overall authority. ${ }^{37}$ Historians of Islamic societies and pre-modern European gender relations alike agree that as long as 'formal mechanisms and structures of the centralized, bureaucratized state' remained weak, arrangements based on kinship took precedence, generally giving women more autonomy and higher social status. ${ }^{38}$ Yet again, this autonomy and elevated status could only be exercised within a patriarchal framework peculiar to the society in question, but, on the whole, it allowed women both greater security and more immediate access to power structures.

Fourth, it is crucially important to assess the place of the female monastic in the spiritual economy of East Slavic societies. It would seem that the expectations of the church hierarchy and society as a whole in this regard were not explicitly high. In earlier periods commitment to Orthodoxy on the part of a monastic community was a staple requirement frequently expressed in foundation charters. However, as Senyk's catalogue of early modern convents demonstrates, political fragmentation of the Belorussian and Ukrainian lands between mutually hostile nations and the absence of support from a 
functioning diocesan apparatus sometimes made conversion and survival synonymous. Migration across the border was another way of escaping confessional pressure, but it could not be accomplished over large expanses of territory. Depending on the political situation, some women's monasteries repeatedly changed between Orthodoxy, Union and Catholicism. ${ }^{39}$ For those that managed to preserve their Orthodox identity, the corollary may have been extreme religious conservatism. The traditional vows of chastity and obedience were expected to be observed, and documents testify that detention, corporal punishment, exile to a provincial monastery, where conditions were comparatively more harsh, or expulsion awaited reprobates and especially repeat offenders. When it came to the vow of poverty, there is a strong impression that it was observed only in those communities where hand-to-mouth existence was a matter of inescapable necessity rather than choice. Otherwise those nuns who were better off lived comfortable lives under noncommunal or idiorrhythmic regimes, and others got by as best they could. These factors conspired against the distinction that has become traditional in the historiography of Catholic convents between the active and the contemplative lifestyles for the female monastic. ${ }^{40}$ In the absence of pressure from above toward assuming a socially proactive role prior to the nineteenth century, individual Greek Catholic and Orthodox nuns may thus have been left to choose between the two callings more or less freely.

The fifth and final question is perhaps the most intriguing of all: how did the nuns cope with the system collectively and individually? For all their apparent shortage of charismatic spirituality, it would perhaps be unwise to regard the inhabitants of East Slavic convents as uniformly apathetic. On the communal level, where faith and salvation of souls appeared to be in danger, religious women did not hesitate to act decisively. When action was required to save their communities from destruction, remarkable resilience was shown. Objects of religious devotion, such as icons, received a lot of attention, and no expense was spared. It is also possible that women were more adaptable and pliant in times of crises. With the onset of the secularisation of monasteries in Ukraine in 1786, the men's St Cyril's Monastery in Kiev was the first to be closed down, while both of its dependent women's convents survived secularisation. The explanation seems straightforward enough: the authorities did not forget the monks' behavior during the plague epidemic of 1770-71, when they refused to cater for the sick or even render 
them spiritual services and fled the monastery for safer places. ${ }^{41}$ The nuns' responses to challenges betray the same characteristic hands-on approach: the energy was there, the problem was how it could be channeled. Neither were religious women passive objects of dictates from above on the individual level: they deployed such measures as were within their grasp, bombarding the authorities with complaints, flouting discipline, escaping, occasionally taking to drink, and, last but not least, producing any amount of internal squabbling and gossip. ${ }^{42}$ While few of these measures amounted to positive action, they undoubtedly represented the nuns' agency directed at the socio-religious system that contained and conditioned them. By making their voices heard, we can start filling significant existing lacunae in religious and gender studies. Apart from its evident scholarly value, research on women's monasticism has a strong element of human interest. As such it holds the potential to broaden the awareness of the place women held in European societies and cultures of the past and to contribute to a more nuanced understanding of it at present. Finally, it will also help to address the problem of integrating parts of Eastern Europe into the larger narrative of European history, and by doing so to 'challenge prevalent European-"non-Western" dichotomies' that still affect the clarity of our historical vision. ${ }^{43}$ 
Early modern female monasticism in the East Slavic lands

\section{WORKS CITED}

Anisimov, E., (ed.), Svoeruchnye zapiski kniagini Natalii Borisovny Dolgorukoi, docheri g[eneral] fel'dmarshala Borisa Petrovicha Sheremet'eva (St Petersburg:

Khudozhestvennaia literatura, 1992)

Bushkovitch, P., [Review:] 'The Cambridge History of Russia. Vol. 1, From Early Rus' to 1689. Ed. Maureen Perrie. Cambridge, Eng.: Cambridge University Press, 2006, etc.', Slavic Review, 67 (2008), 228-9

Carr, T. M., Jr. (ed.), The cloister and the world: early modern convent voices (Charlottesville, VA: Rockwood Press, 2007) (Studies in Early Modern France, 11)

Charipova, L. V., 'Virgins and widows: imperial legislation and practices of admission to the novitiate and profession in Ukrainian women's monasteries (1722-1786)', Slavonic and East European Review, 90 (2012), 262-87

Charipova, L. V., 'Orthodox reform in $17^{\text {th }}$-century Kiev: the evidence of a library', Journal of Early Modern History, 17 (2013), 273-308

Charipova, L. V., 'Earthly mother, holy witch: social perceptions of Maria-Magdalena Mazepa (1687-1707)', Russian History, Special Issue: Witchcraft Casebook: Magic in Russia, Poland, and Ukraine, $15^{\text {th }}-21^{\text {st }}$ Centuries, ed. by Valerie Kivelson, 40 (2013) (forthcoming)

Cruse, M., and H. Hoogenboom (trans.), The memoirs of Catherine the Great (New York: Modern Library, 2006)

Curbet Soler, J., 'Privileges of the soul, pains of the body: Teresa de Jesús, the mystic beatas and the Spanish Inquisition after Trent', in J. Munns, P. Richards (eds.), Gender, power and privilege in early modern Europe (Harlow: Pearson, 2003), 123-39

Dukh, O., 'Kliavzura v zhinochykh uniats'kykh monastyriakh L'vivs'koï ta Peremys'koï ieparkhii XVIII st.: postanovy Zamois'koho synodu ta shchodenna real'nist', Rocznik Europejskiego Kolegium Polskich i Ukraińskich Uniwersytetów (Lublin: Wydawn. Uniwersytetu Marii Curie-Skłodowskiej, 2003), 116-23

Dukh, O., 'Przywileje królewskie dla prawosławnych i unickich monasterów żeńskich w eparchiach lwowskiej i przemyskiej w XVII i XVIII wieku', in M. Derwich, A. PobógLenartowicz (eds.), Klasztor w państwie średniowiecznym i nowożytnym (Wrocław: DiG, 2005), 149-61

Dukh, O., 'Chernytsi monastyriv L'vivs'koï ieparkhiï u 1760-1763 rr.: vikovyi, stanovyi, osvitnii zriz', Sotsium: al'manakh sotsial'nö̈ istoriï, 5 (2005), 59-70 
Dukh, O., 'Nytkarky, svichkarky, proskurnytsi. Mistse remesla v zhinochykh monastyriakh L'vivs'koï ta Peremyshl's'koï ieparkhii u XVII-XVIII stolittiakh', in O. Vinnychenko (ed.), Kriz' stolittia: studiï na poshanu Mykoly Krykuna z nahody 80richchia (Lviv: Naukove tovarystvo im. Shevchenka, 2012), 540-48 (Ukraïnoznavcha naukova biblioteka NTSh, 33)

Emchenko, E. B., 'Zhenskie monastyri v Rossii', in N. V. Sinitsyna (ed.), Monashestvo $i$ monastyri v Rossii, XI-XX veka: istoricheskie ocherki (Moscow: Nauka, 2002), 245-84

Evangelisti, S., 'Wives, widows, and brides of Christ: marriage and the convent in the historiography of early modern Italy', Historical Journal, 43 (2000), 233-47

Evangelisti, S., Nuns: A history of convent life (Oxford: Oxford University Press, 2007)

Fay, M. A., 'Women and waqf: property, power, and the domain of gender in eighteenthcentury Egypt', in M. C. Zilfi (ed.), Women in the Ottoman Empire (Leiden: Brill, 1997), $28-47$

Fitzlyon, K., (ed.), The memoirs of Princess Dashkova (Durham, NC: Duke University Press, 1995)

Frick, D., 'Misinterpretations, misunderstandings, and silences: problems of seventeenthcentury Ruthenian and Muscovite history', in S. H. Baron, N. S. Kollmann (eds.), Religion and culture in early modern Russia and Ukraine (De Kalb, IL: Northern Illinois University Press, 1997), 149-68

Harline, C., 'Actives and contemplatives: the female religious of the Low Countries before and after Trent', Catholic Historical Review, 81 (1995), 541-67

Harline, C., The burdens of Sister Margaret: inside a 17-th century convent (New Haven, CT: Yale University Press, 2000)

Heyberger, B., Hindiyya, mystique et criminelle (1720-1798) (Paris: La Quinzaine littéraire, 2001), recently translated into English as Hindiyya: mystic and criminal, 17201798: a political and social crisis in Lebanon, trans. R. Champion (Cambridge: James Clarke \& Co., 2013)

Heyberger, B., 'Individualism and political modernity: devout Catholic women in Aleppo and Lebanon between the seventeenth and the nineteenth centuries', in A. Sonbol (ed.), Beyond the exotic: women's histories in Islamic societies (Syracuse, NY: Syracuse University Press, 2005), 71-85

Hufton, O. H., (ed.), Women in the religious life (Florence: European University Institute, 1996) 
Early modern female monasticism in the East Slavic lands

Hufton, O., Whatever happened to the history of the nun? (Egham: Royal Holloway, University of London, 2000) (Hayes Robinson Lecture Series, 3).

Istoriia tserkvy ta relihiinoï dymky v Ukraïni, 3 vols (Kiev: Lybid', 1994); 3:

O. P. Kryzhanivs'kyi, S. M. Plokhii, Kinets' XVI-seredyna XIX stolittia

Kivelson, V. A., 'Patrolling the boundaries: witchcraft accusations and household strife in seventeenth-century Muscovy’, Harvard Ukrainian Studies, 19 (1995), 302-23

Kivelson, V. A., 'Through the prism of witchcraft: gender and social change in seventeenth-century Muscovy', in A. Clemens, R. Friedman (eds.), Russian masculinities in history and culture (Basingstoke: Palgrave, 2002), 74-94

Kollmann, N. S., 'The seclusion of elite Muscovite women', Russian History, 10 (1983), $170-87$

Kollmann, N. S., 'Women's honour in early modern Russia', in B. E. Clements, B. A. Engel, C. D. Worobec (eds.), Russia's women: accommodation, resistance, transformation (Berkeley, CA: University of California Press, 1991), 60-73

Kollmann, N. S., 'Concepts of society and social identity in early modern Russia', in S. H. Baron, N. S. Kollmann (eds.), Religion and culture in early modern Russia and Ukraine (De Kalb, IL: Northern Illinois University Press, 1997), 34-51

Kollmann, N. S., “"What's love got to do with it?” Changing models of masculinity in Muscovite and Petrine Russia', in B. A. Clemens, R. Friedman (eds.), Russian masculinities in history and culture (Basingstoke: Palgrave, 2002), 15-32

Kollmann, N. S., 'Self, society and gender in Early Modern Russia and Eastern Europe', in T. A. Meade, M. E. Wiesner-Hanks (eds.), A companion to gender history (Malden, MA: Blackwell Publishing, 2006), 358-70

Krainia, O., Kievskii Vozneseniia gospodnia i sviatykh muchenikov Flora i Lavra zhenskii monastyr' (Kiev: Informatsiino-vydavnychyi tsentr Ukraïns'koï Pravoslavnoï tserkvy, 2002)

Krainia, O., Kyievo-Pechers 'kyi zhinochyi monastyr XVI-pochatku XVIII st. i dolia ioho pam 'iatok (Kiev: Natsional'nyi Kyievo-Pechers'kyi istoryko-kul'turnyi zapovidnyk, 2012)

Kuchumov, V. A., 'Russkoe starchestvo', in N. V. Sinitsyna (ed.), Monashestvo $i$ monastyri v Rossii, XI-XX veka: istoricheskie ocherki (Moscow: Nauka, 2002), 223-44

Laven, M., Virgins of Venice (London: Viking, 2002) 
L[azarevskii], G., 'K istorii kievskikh zhenskikh monastyrei', Kievskaia starina, 53 (1896), 8-13

Leach, C. S. (ed.), Memoirs of the Polish Baroque: the writings of Jan Chryzostom Pasek, a squire of the Commonwealth of Poland and Lithuania (Berkeley, CA:

University of California Press, 1976)

Lehfeldt, E. A., 'Discipline, vocation and patronage: Spanish religious women in a Tridentine microclimate' Sixteenth Century Journal, 30 (1999), 1009-30

Levin, E., Sex and society in the world of the Orthodox Slavs, 900-1700 (Ithaca, NY: Cornell University Press, 1989)

Lowe, K. J. P., 'Female strategies for success in a male-ordered world: the Benedictine convent of Le Murate in Florence in the fifteenth and sixteenth centuries', Studies in Church History, 27 (1990), 209-21

Makhlouf, A. M., 'Hindiye Anne Ajeymi in her ecclesiastical and political situation', Parole d'Orient, 16 (1990-91), 279-87

Makhlouf, A. M., 'Hindiyyah 'Ujaymî and the monastic life: the rule of life for the Congregation of the Sacred Heart', Parole d'Orient, 18 (1993), 293-302

Malizhenovskii, N., Kievskii zhenskii Florovskii (Voznesenskii) monastyr', ed. O. Krainia (Kiev: Feniks, 2010) (this edition of the work, first published in 1894, has extensive and very useful preface and annotations)

Marker, G., Imperial saint: the cult of St Catherine and the dawn offemale rule in Russia (De Kalb, IL: Northern Illinois University Press, 2007)

Michels, G., 'Muscovite elite women and Old Belief', Harvard Ukrainian Studies, 19 (1995), 428-50

Meehan, B., Holy women of Russia: the lives of five orthodox women offer spiritual guidance, $2^{\text {nd }}$ edn (Crestwood, NY: St Vladimir's Seminary Press, 1997)

Meehan-Waters, B., [Review:] 'S. Senyk, Women's monasteries in Ukraine and Belorussia to the period of suppression, Rome, 1983', Harvard Ukrainian Studies, 10 (1986), 259-60

Miller, M. L., 'Under the Protection of the Virgin: the Feminization of Monasticism in Imperial Russia, 1700-1923', PhD diss. (Brandeis University, 2009)

Mohasseb Saliba, S., Les monastères maronites doubles du Liban: entre Rome et l'Empire ottoman (XVIIe-XIXe siècles) (Paris: Geuthner, 2008) 
Early modern female monasticism in the East Slavic lands

Mordvintsev, V. M., Rosiis'ke samoderzhavstvo i Ukraïns'ka pravoslavna tserkva $v$ kintsi XVII-XVIII st. (Kiev: Redaktsiino-vydavnychyi tsentr Kyïvs'koho universytetu, 1997)

Nicol, D. M., The Byzantine lady: ten portraits, 1250-1500 (Cambridge: Cambridge University Press, 1994)

Paert, I., Old Believers, religious dissent and gender in Russia, 1760-1850 (Manchester: Manchester University Press, 2003)

Patlagean, E., 'L'histoire de la femme déguisée en moine et l'evolution de la santeté feminine à Byzance', Studi Medievali, Ser. 3, 17 (1976), 597-623, also repr. in eadem, Structure sociale, famille, chrétienté à Byzance, IV-XIe siècle (London: Variorum Reprints, 1981)

Plokhy, S., The Cossacks and religion in early modern Ukraine (Oxford: Oxford University Press, 2001)

Poutrin, I., Le voile et la plume: autobiographie et santeté féminine dans l'Espagne moderne (Madrid: Casa de Velazquez, 1995)

Pushkareva, N., Women in Russian history from the tenth to the twentieth century, trans. and ed. by E. Levin (Armonk, NY: M. E. Sharpe, 1997)

Rublack, U., 'Meanings of gender in early modern German history', in eadem (ed.), Gender in early modern German history (Cambridge: Cambridge University Press, 2002), 1-18

Schilling, H., 'Confessionalisation and the rise of religious and cultural frontiers in early modern Europe', in E. Andor, I. G. Tóth (eds.), Frontiers of faith: religious exchange and the constitution of religious identities, 1400-1750 (Budapest: History Department, Central European University, 2001), 21-35

Schmähling, A., Hort der Frömmigkeit-Ort der Verwahrung: Russische Frauenklöster in 16.-18. Jahrhundert (Stuttgart: Steiner, 2009)

Senyk, S., Women's monasteries in Ukraine and Belorussia to the period of suppression (Rome: Pont. institutum studiorum orientalium, 1983) (Orientalia Christiana Analecta, 222)

Sokhan', S. V., 'Kyïvs'ki Bohoslovs'kyi ta Iordans'kyi zhinochi monastyri XVIXVIII st.: spletinnia doli v istorychnomu prostori', Rukopysna ta knyzhkova spadshchyna Ukrä̈ny, 13 (2009), 79-98

Strasser, U., 'Cloistering women's past: conflicting accounts of enclosure in a seventeenth-century Munich nunnery', in U. Rublack (ed.), Gender in early modern German history (Cambridge: Cambridge University Press, 2002), 221-46 
Early modern female monasticism in the East Slavic lands

Strasser, U., State of virginity: gender, religion, and politics in an early modern Catholic state (Ann Arbour, MI: University of Michigan Press, 2007) (Social History, Popular Culture, and Politics in Germany)

Talbot, A.-M., 'Bluestocking nuns: intellectual life in the convents of late Byzantium', Harvard Ukrainian Studies, 7 (1983), 604-18

Talbot, A.-M., 'Late Byzantine nuns: by choice or necessity?', Byzantinische Forschungen, 9 (1983), 103-117

Talbot, A.-M., 'A comparison of the monastic experience of Byzantine men and women', Greek Orthodox Theological Review, 30 (1985), 1-20

Thaisia, Abbess, The autobiography of a spiritual daughter of St John of Kronstadt (Platina, CA: Saint Herman Press, 1989)

Thaisia, Abbess, Letters to a beginner: on giving one's life to God (Wildwood, CA: Saint Herman Press, 1993)

Thomas, M. A., 'Managerial roles in the Suzdal'skii Pokrovskii Convent during the seventeenth century', Russian History, 7 (1980), 92-112

Thomas, M. A., 'Muscovite convents in the seventeenth century', Russian History, 10 (1983), 230-42

Thyrêt, I., Between God and Tsar: religious symbolism and the royal women of Muscovite Russia (De Kalb, IL: Northern Illinois University Press, 2001)

Van Wyhe, C., (ed.), Female monasticism in early modern Europe: an interdisciplinary view (Aldershot: Ashgate, 2008)

Walker, C., 'Securing souls or telling tales? The politics of cloistered life in an English convent', in C. van Wyhe (ed.), Female monasticism in early modern Europe: an interdisciplinary view (Aldershot: Ashgate, 2008), 227-44

Watt, J. R., The scourge of demons: possession, lust, and witchcraft in a seventeenthcentury Italian convent (Rochester, NY: Univesity of Rochester Press, 2009)

Weber, A., Teresa of Avila and the rhetoric of femininity (Princeton, NJ: Princeton University Press, 1996)

Weeks, T. R., “"Western civilization” and Russian/ "Eastern European” history', News Net: News of the American Association for the Advancement of Slavic Studies, 50, no. 2 (March 2010), 3-10 
Weyl Carr, A., 'Women and monasticism in Byzantium: introduction from an art historian', Byzantinische Forschungen, 9 (1983), 1-15

Wiesner-Hanks, M. E., Women and gender in early modern Europe, $3^{\text {rd }}$ edn (Cambridge: Cambridge University Press, 2008)

Woodford, C., Nuns as historians in early modern Germany (Oxford: Oxford University Press, 2002)

Woodford, C., 'Convents and writings by nuns', in M. Spongberg, A. Curthoys, B. Caine (eds.), Companion to women's historical writing (Basingstoke: Palgrave Macmillan, 2005), 104-12

Woodford, C., 'Writing the Thirty Years' War: convent histories by Maria Anna Junius and Elizabeth Herold', in C. van Wyhe (ed.), Female monasticism in early modern Europe: an interdisciplinary view (Aldershot: Ashgate, 2008), 245-60.

\footnotetext{
* The collective designation 'East Slavic lands' refers to the the territory occupied by present-day Belorussia, Ukraine and European Russia, where in the medieval and early modern periods Christian Churches of the Eastern Rite commanded the allegiance of the majority of population.

${ }^{1}$ Evangelisti, Nuns, 1.

${ }^{2}$ Monographs: Weber, Teresa of Avila; Harline, The burdens of Sister Margaret; Laven, Virgins of Venice; Strasser, State of virginity; Watt, The scourge of demons. Edited collections: Hufton (ed.), Women in the religious life; Carr, Jr. (ed.), The cloister and the world; van Wyhe (ed.), Female monasticism in early modern Europe. Articles: Lowe, 'Female strategies for success'; Harline, 'Actives and contemplatives'; Lehfeldt, 'Discipline, vocation and patronage'; Evangelisti, 'Wives, widows, and brides of Christ'; Strasser, 'Cloistering women's past'; Curbet Soler, 'Privileges of the soul'.

${ }^{3}$ Hufton, Whatever happened to the history of the nun?, 5.

4 'Eastern Christianity' is a blanket term that describes Christian traditions and churches, which maintain a distinct system of religious rites that are commonly associated through their historical origins with Byzantium and Hellenic East. This division is fairly aritificial, however, as some Eastern Churches, such as the Maronites of Syria and Lebanon or Greek Catholics of Eastern Europe have been in communion with Rome for centuries and hold more in common with Latinate Western confessions than with any Eastern church.

${ }^{5}$ Patlagean, 'L'histoire de la femme déguisée en moine'; Talbot, 'Bluestocking nuns'; eadem, 'Late Byzantine nuns'; eadem, 'A comparison of the monastic experience of Byzantine men and women'; Weyl Carr, 'Women and monasticism in Byzantium'; also see Nicol, The Byzantine lady, 33-47, 59-70.

${ }^{6}$ Makhlouf, 'Hindiye Anne Ajeymi'; eadem, 'Hindiyyah 'Ujaymî and the monastic life'; Heyberger, Hindiyya, mystique et criminelle, recently translated into English as Hindiyya: mystic and criminal; idem, 'Individualism and political modernity'; Mohasseb Saliba, Les monastères maronites doubles du Liban.

${ }^{7}$ Istoriia tserkvy ta relihiinoï dymky v Ukraïni, vol. 3, 283-284.
} 
${ }^{8}$ See Thomas, 'Managerial roles in the Suzdal'skii Pokrovskii Convent'; eadem, 'Muscovite convents in the seventeenth century'; Miller, 'Under the protection of the Virgin'. For a broad overview of Russian female monasticism see Emchenko, 'Zhenskie monastyri v Rossii'; Schmähling, Hort der Frömmigkeit - Ort der Verwahrung.

${ }^{9}$ Senyk, Women's monasteries in Ukraine and Belorussia. For a review of the book by Brenda Meehan-Waters see Harvard Ukrainian Studies, 10 (1986), 259-60.

${ }^{10}$ Dukh, 'Kliavzura v zhinochykh uniats'kykh monastyriakh'; idem, 'Przywileje królewskie dla prawosławnych i unickich monasterów żeńskich'; idem, 'Chernytsi monastyriv L'vivs'koï ieparkhiï u 1760-1763 rr.'; idem, 'Nytkarky, svichkarky, proskurnytsi'.

${ }^{11}$ Malizhenovskii, Kievskii zhenskii Florovskii (Voznesenskii) monastyr'; Krainia, Kievskii Vozneseniia gospodnia i sviatykh muchenikov Flora i Lavra zhenskii monastyr'; eadem, Kyievo-Pechers 'kyi zhinochyi monastyr XVI-pochatku XVIII st.

${ }^{12}$ Sokhan', 'Kyïvs'ki Bohoslovs'kyi ta Iordans'kyi zhinochi monastyri XVI-XVIII st.'; Charipova, 'Virgins and widows'; eadem, 'Earthly mother, holy witch'.

${ }^{13}$ Monographs: Levin, Sex and society in the world of the Orthodox Slavs; Thyrêt, Between God and Tsar; Paert, Old Believers, religious dissent and gender in Russia; Marker, Imperial saint. Articles: Kollmann, ‘The seclusion of elite Muscovite women'; eadem, 'Women's honour in early modern Russia'; eadem, "'What's love got to do with it?"'; eadem, 'Self, society and gender in Early Modern Russia and Eastern Europe'; Kivelson, 'Through the prism of witchcraft'; eadem, 'Patrolling the boundaries'; Michels, 'Muscovite elite women and Old Belief'.

${ }^{14}$ See, for instance, Wiesner-Hanks, Women and gender in early modern Europe, 211, 232-4.

${ }^{15}$ Frick, 'Misinterpretations, misunderstandings, and silences', 151.

${ }^{16}$ Senyk, Women's monasteries in Ukraine and Belorussia, 105-110.

${ }^{17}$ Bushkovitch, 'The Cambridge History of Russia', 228-9.

${ }^{18}$ Schilling, 'Confessionalisation and the rise of religious and cultural frontiers', 22, cf. Plokhy, The Cossacks and religion in early modern Ukraine, 10-12; Charipova, 'Orthodox reform in $17^{\text {th }}$-century Kiev', 295-99.

${ }^{19}$ Kollmann, 'Concepts of society and social identity in early modern Russia', 34; eadem, 'Self, society and gender', 365; also see Thomas, 'Muscovite convents in the seventeenth century', 234.

${ }^{20}$ Seventeenth-century Polish diaristic literature is a rich, varied and widely applied source of historical information, see, for instance, Leach (ed.), Memoirs of the Polish Baroque.

${ }^{21}$ For comparison, based on statistics derived from Poutrin, Le voile et la plume, Evangelisti cites the figure of 113 spiritual biographies written by Catholic nuns between the end of the sixteenth and mid-seventeenth centuries in Spain alone: Evangelisti, Nuns, 71. On the German nun chroniclers see Woodford, Nuns as historians in early modern Germany; eadem, 'Convents and writings by nuns'; eadem, 'Writing the Thirty Years' War'.

${ }^{22}$ Such as the life of the Old Believer saint Feodosiia Morozova: Michels, 'Muscovite elite women', 428, n. 2, 430.

${ }^{23}$ L[azarevskii], 'K istorii kievskikh zhenskikh monastyrei', 10. 
${ }^{24}$ Anisimov (ed.), Svoeruchnye zapiski kniagini Natalii Borisovny Dolgorukoi; see also Pushkareva, Women in Russian history, 132-3. Two other remarkable eighteenth-century laywomen in Russia left their memoirs, see Cruse, Hoogenboom (eds.), The memoirs of Catherine the Great; Fitzlyon (ed.), The memoirs of Princess Dashkova.

${ }^{25}$ Abbess Thaisia, The autobiography of a spiritual daughter of St John of Kronstadt. She also published a series of letters addressed to novices: eadem, Letters to a beginner. On Thaisia see Meehan, Holy women of Russia, 83-124.

${ }^{26}$ Thaisia, The autobiography, 25, cf. Weber, Teresa of Avila, 42-3.

${ }^{27}$ Kollmann, 'Concepts of society and social identity', 42.

${ }^{28}$ Kollmann, 'Self, society and gender', 359.

${ }^{29}$ Kollmann, "What's love got to do with it?", 15-16.

${ }^{30}$ Rublack, 'Meanings of gender in early modern German history', 1.

${ }^{31}$ Wiesner-Hanks, Women and gender in early modern Europe, 217.

${ }^{32}$ Charipova, 'Virgins and widows', 272-273.

${ }^{33}$ Kollmann, 'Self, society and gender', 365.

${ }^{34}$ Kollmann, 'The seclusion of elite Muscovite women'.

${ }^{35}$ Charipova, 'Earthly mother, holy witch'.

${ }^{36}$ Senyk, Women's monasteries in Ukraine and Belorussia, 19-20, 30, 40, 116-117;

Kuchumov, 'Russkoe starchestvo', 255-6.

${ }^{37}$ For the familial origins of the double monastery see Mohasseb Saliba, Les monastères maronites doubles, 48-9, 57-63.

${ }^{38}$ Fay, 'Women and waqf', 33.

${ }^{39}$ Senyk, Women's monasteries in Ukraine and Belorussia, 11-50.

${ }^{40}$ See Harline, 'Actives and contemplatives', 563-7.

${ }^{41}$ Mordvintsev, Rosiis'ke samoderzhavstvo i Ukraïns 'ka pravoslavna tserkva, 61-3.

${ }^{42}$ On monastic gossip as a means of social control see Walker, 'Securing souls or telling tales?', 240-44.

${ }^{43}$ Weeks, “Western civilization” and Russian/ "Eastern European” history', 10. 